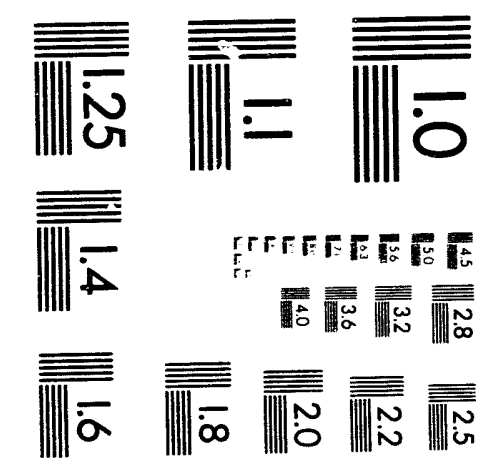




$$
1
$$
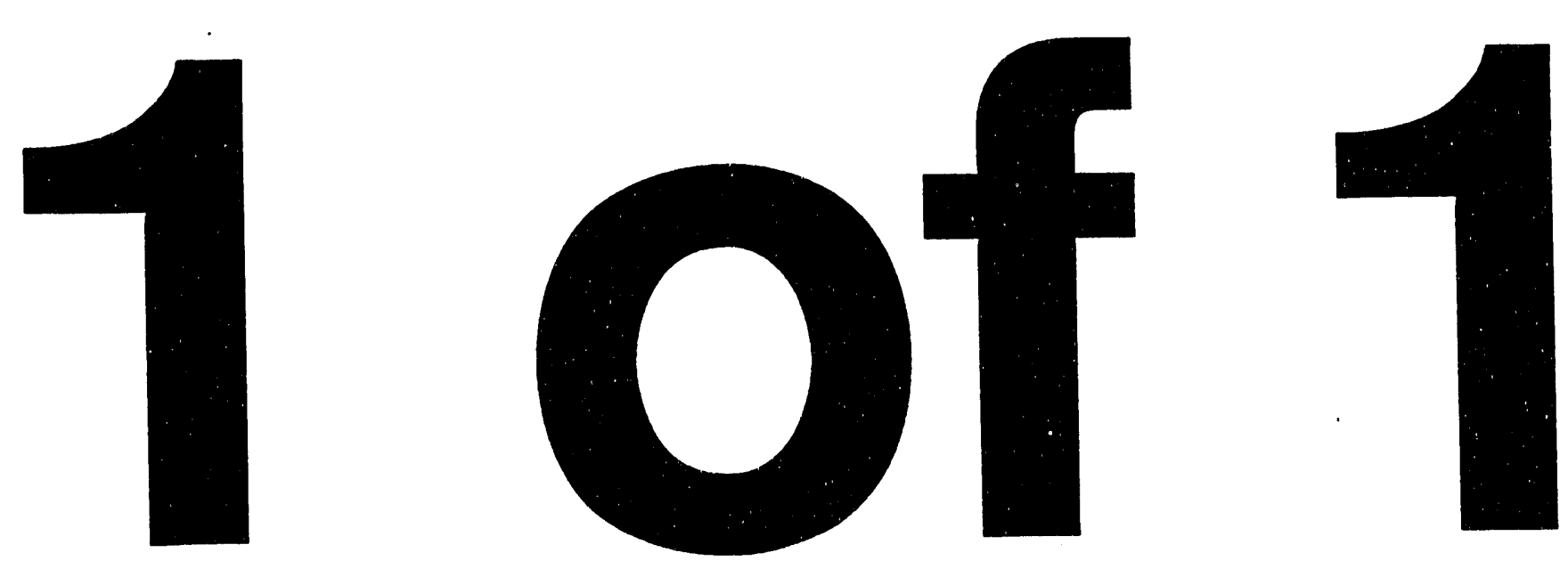


\section{GROUNDWATER PENETRATING RADAR AND HIGH RESOLUTION SEISMIC FOR LOCATING SHALLOW FAULTS IN UNCONSOLIDATED SEDIMENTS (U)}

by

D. E. Wyatt

Westinghouse Savannah River Company

Savannah River Site

Aiken, South Carolina 29808

M. G. Wadell

B. Sexton

This paper was prepared in connection with work done under the above contract number with the U. S.

Department of Energy. By acceptance of this paper, the publisher and/or recipient acknowledges the U. S. Government's right to retain a nonexclusive, royalty-free license in and to any copyright covering this paper, along with the right to reproduce and to authorize others to reproduce all or part of the copyrighted paper. 


\section{DISCLAIMER}

This report was prepared as an account of work sponsored by an agency of the United States Government. Neither the United States Government nor any agency thereof, nor any of their employees, makes any warranty, express or implied, or assumes any legal liability or responsibility for the accuracy, completeness, or usefulness of any information, apparatus, product, or process disclosed, or represents that its use would not infringe privately owned rights. Reference herein to any specific commercial product, process, or service by trade name, trademark, manufacturer, or otherwise does not necessarily constitute or imply its endorsement, recommendation, or favoring by the United States Government or any agency thereof. The views and opinions of authors expressed herein do not necessarily state or reflect those of the United States Government or any agency thereof.

This report has been reproduced directly from the best available copy.

Available to DOE and DOE contractors from the Office of Scientific and Technical Information, P. O. Box 62, Oak Ridge. TN 37831; prices available from (615) 576-8401.

Available to the public from the National Technical Information Service, U. S. Deparment of Commerce, 5285 Port Royal Rd., Springfield, VA 22161 


\section{RECEIVED \\ MAR 031994 \\ OSTI}

GPR and High Resolution Seismic for Locating Shallow Faults in

Unconsolidated Sediments

Douglas E. Wyatt

Westinghouse Savannah River Company

Aiken, South Carolina

and

Earth Sciences and Resources Institute

University of South Carolina, Columbia, SC

Michael G. Waddell Earth Sciences and Resources Institute

University of South Carolina, Columbia, SC

G. Boyd Sexton Microseeps, Inc.

Pittsburgh, Pennsylvania 
Faults in shallow, unconsolidated sediments, particularly in coastal plain settings, are very difficult to discern during subsurface exploration yet have critical impact to groundwater flow, contaminant transport and geotechnical evaluations. This paper presents a case study using cross-over geophysical technologies in an area where shallow faulting is probable and known contamination exists. A comparison is made between Wenner and dipoledipole resistivity data, ground penetrating radar, and high resolution seismic data. Data from these methods were verified with a cone penetrometer investigation for subsurface lithology and compared to existing monitoring well data. Interpretations from these techniques are compared with actual and theoretical shallow faulting found in the literature. The results of this study suggests that 1) the CPT study, combined with the monitoring well data may suggest that discontinuities in correlatable zones may indicate that faulting is present 2) the addition of the Wenner and dipole-dipole data may further suggest that offset zones exist in the shallow subsurface but not allow specific fault planes or fault stranding to be mapped 3) the high resolution seismic data will image faults to within a few feet of the surface but does not have the resolution to identify the faulting on the scale of our models, however it will suggest locations for upward continuation of faulted zones 4) offset $100 \mathrm{MHz}$ and $200 \mathrm{MHz}$ CMP GPR will image zones and features that may be fault planes and strands similar to our models 5) $300 \mathrm{MHz}$ GPR will image higher resolution features that may suggest the presence of deeper faults and strands, and 6) the combination of all of the tools in this study, particularly the GPR and seismic may allow for the mapping of small scale, shallow faulting in unconsolidated sediments. 
The disruption of sediment and soils associated with near surface and surface faulting in shallow, unconsolidated sediments is often difficult to discern during subsurface investigations. Numerous studies suggest that near surface faulting in unconsolidated sediments exists in a variety of forms and may not be obvious even in areas where surface displacement has occurred (Bonilla, 1972; Bonilla and Lienkaemper, 1990; Crone and Luza, 1990).

The presence of shallow faulting in the alternating sands and clays of the southeastern coastal plain is important for understanding the hydrogeologic conditions associated with these lithologies since shallow faults may act as preferential pathways for horizontal flow, or as conduits for vertical flow between aquifer systems. The presence of deeper faulting, which may be a geotechnical hazard, may also be indicated by shallow expression. Acting as a horizontal pathway, a fault may channel contaminants from a source to areas not predicted in conventional groundwater flow modeling. Evidence of shallow faulting, acting as a vertical pathway, is further described in Nielson, 1991. Discussions of geotechnical hazards associated with near surface faulting are found in a variety of engineering geology and civil engineering literature and the reader is referred to journals in those disciplines for further information.

Examples of shallow faulting used for comparison in this study are modified from Bonilla and Lienkaemper (1990), Roth et al (1981), D'Appolonia (1979) and Witboard et al (1993). In coastal plain sediments, numerous faults, clastic dikes and sinks are known (Seeber and Armbruster, 1983, D'Appolonia, 1979) and this paper examines and compares several techniques for identifying the 
location and character of shallow faults within the Savannah River Site, a large (309 sq. mi.) DOE facility in the South Carolina coastal plain (Figure 1). Earthquakes with epicenters within the Savannah River Site are known (Stephenson, 1985, 1988) which may suggest that historical localized earthquake activity may have affected the shallow subsurface. Marine and Siple (1974) and Cumbest et al (1992) describe a fault bounded Triassic basin underlying the SRS which may also effect localized shallow faulting.

The shallow geology of the study area, inferred from monitoring well geophysical logs and drill core is shown on Figure 2. This area is adjacent to several large waste sites and was chosen because of the numerous groundwater monitoring wells nearby and because possible faults were inferred from the localized subsurface data. Monitoring wells within the study area have detected contamination in a deeper aquifer which suggests vertical flow.

Groundwater and surface water characteristics within the coastal plain are largely controlled by physiography and subsurface stratigraphy. The study area is underlain by a seaward-thickening wedge of unconsolidated and semiconsolidated fluvial, deltaic, and marine sediments. The Late Cretaceous to Holocene sediments are approximately 1,200 feet thick and are generally saturated to near surface depths.

Traditional Wenner array surface resistivity, is combined with dipole-dipole data, 10 cone penetrometer tests, three ground penetrating radar configurations and a high resolution seismic reflection survey. A comparison of the standard techniques with the CPT, GPR and high resolution seismic combination is made to determine the adequacy of these techniques for shallow fault delineation. 


\section{METHODS}

The existing borehole information and CPT data are used as standards and are compared to the Wenner resistivity survey, a dipole-dipole resistivity survey, the high resolution seismic survey and the three GPR frequency and antenna configurations. These techniques and use in this study are briefly described below.

\section{Cone Penetrometer Data}

The cone penetrometer is routinely used in engineering geological studies and is becoming more widely used in environmental characterization. This technique uses a truck mounted hydraulic system to push an instrumented probe or sampler into soft sediments, often for hundreds of feet. The probe instrument, typically $35.7 \mathrm{~mm}$ in diameter with a tip apex angle of $60^{\circ}$, records at a minimum, sleeve friction and tip resistance, and may record resistivity, natural gamma, spontaneous potential, velocity and sonic data, pieziometric values and a variety of other geological and geotechnical parameters. Parameters may be manipulated to produce logs, similar to geophysical logs, that may then be correlated for an understanding of the shallow geology. This technique has particularly been used in studying submarine geology (for example, see Hampton et al, 1982). It is also possible to obtain soil and water samples with many types of CPT tools for direct stratigraphic and contaminant identification. Lithology types and densities may also be indirectly determined for calibration of other geophysical techniques. An excellent discussion of the direct push technique is found in Robertson and Campanella, (1989). 
Ten direct push locations were used to provide additional shallow subsurface information. Three monitoring wells with gamma logs and core descriptions are also used to correlate with the CPT data. The spacings and relative depths of these locations are shown on Figure $3 a$.

\section{Resistivity}

Surface resistivity is a well known and understood geophysical tool and has been used in shallow fault investigations in unconsolidated sediments (for example, Krieter and McKalips, (1978) and Andrews, (1961)) and is very often used in mapping shallow subsurface structures. The body of literature relating Wenner and dipole-dipole surveys with depth correlations is extensive and these methods were chosen to key on the overlapping depths in which shallow faulting was expected. This study utilized traditional Wenner profiling and followed an approach similar to that applied by Stearns et al (1986) and Haselton and Tsau (1986) for locating a fault in unconsolidated sediments in the Mississippi Embayment, which are similar to those of the study area. Additionally, a dipole-dipole profiling/sounding survey was conducted in an attempt to investigate deeper structure for a more direct comparison to the existing geological cross-section. Data was acquired along an east-west, 1000 foot transect centered on monitoring well HSB-69 and CPT-1 and along the line of the CPT borings. The Wenner data was acquired from east to west and the dipole-dipole data from west to east. Figure $3 b$ shows the results from these surveys. 
The Wenner data was acquired using three 'A' spacings of 20,40 and 80 feet. Profiling was accomplished by keeping the eastern current electrode fixed for each ' $A$ ' spacing and moving the remaining electrodes the appropriate distances, therefore, each profile has different center points. Following Beck (1981), the ' $A$ ' spacings used generated apparent resistivities from 7', 13' and $27^{\prime}$ respectively which are shown on Figure $3 b$.

A dipole-dipole survey (Bodmer and Ward, 1969 and Ward, 1990) was also performed for investigation of deeper electrical structure. Work by Ross et al (1990) and more recently in South Carolina by Waddell, (personal communication, 1993), suggests that this method has applicability as a comparison for this study.

A dipole-dipole profile/sounding, with a 40 foot $N$ spacing, up to $N=4$, was acquired along the study line. The $\mathrm{N}$ spacings assumed a $35 \%$ depth of investigation for the dipole-dipole configuration (Beck, 1981), therefore, $N=1$ through $\mathrm{N}=4$ investigated $42^{\prime}, 56^{\prime}, 70^{\prime}$ and $84^{\prime}$ respectively. The results from this profiling and sounding are shown on Figure $3 \mathrm{~b}$.

\section{High Resolution Seismic Survey}

A high resolution seismic survey was conducted over the study area in the summer of 1993 using a 48 channel EG\&G 2401 seismograph and a Bison Instruments Elastic Wave Generator (EWG-1). $100 \mathrm{~Hz}$ geophone spacing was six feet and shot spacing was six feet with a nine foot near offset. Each shot was stacked three times. A $100 \mathrm{~Hz}$ low cut filter and $60 \mathrm{~Hz}$ notch were used with a 0.20 ms sampling interval over a 409 ms record. Velocity control was estimated 
using nearby refraction data, a nearby monitoring well with sonic data and generally accepted values for unconsolidated, water saturated sands. The high resolution data, with interpreted faulting, is seen in Figure 4. Only those faults thought to affect the study area are shown.

The high resolution data was processed using the following sequence: geometry, amplitude balancing, deconvolution, F-K filter, gather, velocity analysis, NMO, mute, DMO and stack. Several noise trains were evident throughout the field data and were associated with truck bouncing caused by the EWG-1 and possibly with elastic rebound associated with the hammer to plate contact. These noise sources were removed with the F-K filter.

\section{Ground Penetrating Radar}

Two GPR systems, a Pulse Ekko-IV and GSSI SIR-10, were used in the study with three antenna frequencies and configurations; a GSSI $100 \mathrm{MHz}$ in-line bistatic configuration, a Pulse Ekko $200 \mathrm{MHz}$ system used in a CMP mode and a GSSI $300 \mathrm{MHz}$ monostatic antenna. For basic GPR theory see Moffat and Puskar (1979), Ulriksen (1982), Davis and Annan (1988), Beres and Haeni (1991), Annan and Cosway (1992), Fisher et al., (1992) and Wyatt et al, (1993).

The $100 \mathrm{MHz}$ bistatic data was acquired using two channels on a SIR System10 in a transmitter and receiver, zero offset and transmitter to receiver, five foot offset configuration using the GSSI high power transducers. The best data with least noise was provided by the five foot offset configuration using a fiber optics connector and is used for this study. The overall appearance of the zero offset $100 \mathrm{MHz}$ data is similar to the $300 \mathrm{MHz}$ data discussed below. Vertical scan 
record length was 600 ns with 512 samples per scan or a 1.17 ns sampling interval (100 cycles per scan). This configuration returned data from an approximate depth of 42 feet. Table 1 describes the processing applied to the raw data for each GPR line. A very mild, 20 sample vertical low and high cut filter was applied to the data to act as a bandpass noise filter. A horizontal low cut filter was used to sum 20 horizontal traces to each center trace and effectively stack the data. There are 32.8 scans per meter, therefore a 20 trace stack allows for an approximate averaging of 0.67 meters, or $1 / 3$ of the calculated Fresnel zone at 200 ns, moderately smoothing horizontal features and reducing potential noise problems.

The $200 \mathrm{MHz}$ data was acquired with a Pulse Ekko-IV system using a CMP technique. This technique is discussed in Annan and Cosway (1992). The multioffset CMP method used a $3^{\prime}$ antenna spacing with 16 walkaway shotpoints three feet apart. A three foot offset was chosen because 1) this spacing is the largest interval (i.e. sampling two parts per wavelet) for a $200 \mathrm{mHz}$ system seeking unaliased sampling or wavelets assuming a soil velocity of $0.5 \mathrm{ft} / \mathrm{ns}$, and 2) a three foot interval allowed for more rapid surveying. It should be noted that actual velocities, using this technique, found were approximately $0.3 \mathrm{ft} / \mathrm{ns}$ and that some spatial aliasing occurred (Hu et al, 1992). Record length was $1 \mu \mathrm{s}$ with a sampling rate of 0.8 nanoseconds.

The third GPR technique used the SIR System 10 in a single channel mode with a fixed $300 \mathrm{MHz}$ antenna. Record length was 300 ns with a vertical sampling interval of 1024 samples per scan or a sampling rate of 0.3 nanoseconds. The horizontal sampling interval was 32.8 scans per meter. Mild filtering was applied similar to the $100 \mathrm{MHz}$ data. This technique acquired inforrmation to a 
usable depth of investigation of about 100 ns or about 15 feet. Table 1 describes the processing used for this data.

Processing of the $100 \mathrm{MHz}$ and $300 \mathrm{MHz}$ data was completed using the GSSI Radan III software. No static corrections were applied because of only minor topographic changes along the portions of the transect used for this study. The $200 \mathrm{MHz}$ data was processed by the Houston Advanced Research Center with seismic software inodified for GPR velocities. Static corrections were applied to this data because it covered a longer transect and topography was a factor, however, the portion of the data used for this study was essentially flat.

\section{DISCUSSION}

It is not possible to trench or directly observe the small scale faulting this paper explores because of environmental ano contaminant concerns. Therefore, examples of shallow faulting in unconsolidated sediments from the literature and from trenching in uncontaminated areas within the general region of the study area are used as a comparison. Figures 5a-d are examples of faulting in shallow unconsolidated sediments. These examples, or variations, are the general style of faulting expected to be imaged from the techniques discussed below.

\section{High Resolution Seismic Data}

The high resolution seismic data is shown on Figure 4. This high quality data images obvious offset reflectors at shallow (approximately 30-35 feet) horizons and deeper. This data is correlated with the resistivity, CPT and radar data sets 
by the locations of the CPT holes shown as black tic marks at the top of the figure. Abruptly terminating reflectors, changes in amplitude and frequency and reverses in polarity are positive indications of structural offset with depth. Fault traces are more difficult to follow through the Cretaceous section (beginning about 0.1 milliseconds), however, using the criteria described in Campbell (1965) and Sheriff (1982), it is possible to extrapolate faulting from basoment to the upper resolution of the data.

Work by Goforth and Hayward (1992), Knapp and Steeples (1986 a \& b), Miller et al (1990), more recently from 2D and 3D work in progress by the authors supports new techniques for very high resolution seismic imaging of the shallow (zero to $200+$ feet) subsurface for the indication and detection of shallow faulting.

The fault pattern is similar to structural styles and features described in Genik (1993) for similar age rift basinal faulting in Africa. Listric normal faults with concurrent synthetic and rotational secondary faults, form a characteristic growth fault pattern. Some features of the fault system, may indicate that a recent reactivation of the fault has added a transpressional shear and reverse motion component to the system (Apperson and Waddell, 1993) and similar to that observed by Sexton and Jones (1986).

Using the CPT and monitoring well locations marked on the seismic data, it is possible to project deeper faulting continuity to the surface and identify the area to evaluate for expressions of small scale faulting in the near surface.

\section{CPT Data}


Figure $3 A$ is a geologic cross-section created from the CPT data. CPT curves (for example 1, 2E, 2W) are a presentation of the Friction Ratio, or ratio of the tip resistance versus the sleeve resistance and are interpreted much like natural gamma curves (the natural gamma curves for the three nearest monitoring wells are shown for comparison to the FR curves). Values to the left are usually sands and values to the right are usually silts or clays. The exact depth to the water table at the time of this study (during an extended drought) is shown. The correlations between the Friction Ratio logs and the gamma ray curves for wells HSB-84, 69 and 127 are good and provide a basis for comparison between all of the CPT pushes. The shaded horizons are a sand interval used as a reference for discussions.

No direct faults are inferred from the shape of the cross-sectional profile and there are no features immediately comparable to Figure 5 . The location, dip and sense of motion of flexures between $5 \mathrm{~W}$ and $2 \mathrm{~W}$ and associated with $3 E$ may imply a structural origin because the bed thicknesses are unchanged. Also, faulting may be inferred because of the possible repeated section seen in $4 \mathrm{~W}$ (and maybe $5 \mathrm{~W}$ ).

Correlating Figure $3 a$ with Figure 4 suggests that faulting should be observed on the CPT cross section between $5 E$ and $4 E, 3 E$ and $2 E, 2 E$ and 1 , and between $5 \mathrm{~W}$ and $6 \mathrm{~W}$. No direct offset is seen on the CPT cross-section but the flexures associated with $5 \mathrm{~W}$ and $3 \mathrm{E}$ support the faulting interpretation. It is interesting to note that it was possible to push to the silt/clay horizon found at the approximate 130' depth in $3 \mathrm{~W}, 2 \mathrm{~W}, 1 \mathrm{~W}, 1$ and $2 \mathrm{E}$, between areas of inferred faulting. If all pushes are of equal force and the principal variables are 
subsurface lithologies, then maximum push resistance depth may suggest that the silt/clay horizon seen in location 1, may be the same horizon seen in the shallower pushes but outside of the faulted areas.

Resistivity

Because the overburden was relatively resistant $(7000-8000$ ohm-feet) relative to observed values at depth ( 0 to $800 \mathrm{ohm}$ feet) it is felt that the observed apparent resistivities are valuable for interpreting the subsurface geology.

Krietler and McKalips (1978) found that horizontal Wenner profiling was not always successful in locating shallow faults but in some cases the changes in apparent resistivity across a fault were apparent. Rapid changes of several hundreds to thousands of ohm/feet in the shallow Wenner data, corresponding with changes in the dipole-dipole data from this study may suggest the presence of faults at the surface. These data are only potential indicators of faulting and cannot precisely identify a fault cut or plane.

For the dipole-dipole data on Figure $3 b$ the overall observed pattern of the resistivity contours is similar to examples from data over ore bodies (for example, see Pelton et al, 1978) but the best observed comparison is seen from the observations of Ross et al (1990) for complexly disturbed areas associated with slumps and faults in Utah. Additionally, a sense of motion might be inferred from the contours of the data (adjacent to $4 \mathrm{E}$, for example) if it is assumed that higher resistivities indicate the presence of near surface material and low resistivities indicate the presence of deeper material. If generally lower values are adjacent to higher values, then it might be assumed that deeper material is 
adjacent to shallower material, or vice versa (similar to fault example $5 d$ ). It is possible that the resistivity values are imaging a channel cut and fill, however, this does not appear to be consistent with the CPT data. The general alignment of contour interval changes, dipping eastward between $5 \mathrm{~W}$ and $2 \mathrm{~W}$, correlates well with the CPT data. Westward dipping values between $5 E$ and $4 E$ also agree with the CPT data. Overall, the resistivity data do not provide sufficient resolution for determining fault presence or orientation. The combination of the CPT and resistivity data constrain the interpretation to suggest that differences in resistivity, when combined with differences in CPT lithologies, may more strongly suggest that a fault is present and give some morphological information but not allow interpretation of faulting on the scale of our comparison models.

\section{Ground Penetrating Radar}

Seven GPR profiles are shown on Figure 6a-g. These lines are aligned with the locations of the CPT holes and labeled appropriately. CPT holes $5 \mathrm{w}, 1$ and $5 \mathrm{E}$ are shown. The remaining CPT locations are shown in the correct location as black dots. Table 1 describes the general processing parameters for each line. Techniques for the seismic style processing of GPR data are discussed in Fisher et al (1992) and $\mathrm{Hu}$ et al (1992). The use of multiple antenna frequencies is discussed in Davis and Annan (1989) and Smith and Jol (1992). The projected zones of faulting from the seismic data (Figure 4) are also shown on Figure 6 and labeled as " $f z "$.

All data was acquired during the South Carolina drought of 1992 . The overall seasonal variation of moisture remained steady throughout the study and the variations noted in Roberts et al (1991) are not thought to affect the data. 
However, the authors have noted the effects of moisture fronts as they move downward through the soil column in other GPR studies. Lithostratigraphic correlations are good for the single velocity $(6-7 \mathrm{~ns} / \mathrm{ft})$ model, since the water table is so close to the surface. However, if the water table had been deeper, it is felt that a two velocity model would be appropriate (Killey and Annan, 1985).

Figures 6a-d are $100 \mathrm{MHz}$ data presented with increasing amounts of processing applied. These lines used a record length of $600 \mathrm{~ns}$ with $400 \mathrm{~ns}$ displayed. No usable data was available below $400 \mathrm{~ns}$ and much of the data below 300 ns is questionable. The wavy character of the reflectors between 50 and 150 ns located between $6 \mathrm{~W}$ and 1 (see arrows on 6a) on all radar transects may be interpreted as a bedded sand and silt channel following the suggestions of Beres and Haeni (1991) and confirmed by the sand lenses interpreted from the CPT data. Hummacky reflectors surrounding this feature may indicate discontinuous bedded sands and gravels. The horizontal reflector consistent across the data is the water table (Annan et al, 1991), labeled "wt" on the figure. However, the complex angular and broken reflectors may suggest the presence of fracturing and faulting offset. Because this zone correlates with an area of inferred faulting from the seismic and CPT data, it is thought that the GPR is imaging unconsolidated fracturing and fault stranding in a bed or channel containing bedded sands and silts.

Faulting criteria used for the radar data are those of Sheriff (1982) defined for seismic data and include 1) abrupt reflector terminations, 2) direct fault plane reflections, 3) presence of diffractions especially at a termination, 4) visible drag and rollover, 5) correlations of reflectors across a fault plane and possibly 6) loss of coherency beneath a fault plane or distorted dips seen through the fault 
plane. The presence of offset on some reflectors while unbroken on others may be explained by shear or fault reversal on dip slip planes (DePaor and Eisenstadt, 1987).

Figure 6 a shows the $5^{\prime}$ offset data with numerous shadows, apparent velocity contrasts, dip and bedding changes and diffractions that are thought to be associated with small scale faulting with offsets on the order of 10 to 20 ns (see Crone and Luza, 1990) The presence of channel fill between possible fault traces may suggest that faulting was syndepositional while the presence of fracture traces through the sand body (see 6c) suggests later motion or reactivation of the fault. Numerous vertical offsets, difficult to distinguish on the other lines but apparent on $6 c$, are possibly fault stranding similar to our reference model $3 \mathrm{~A}$. Figure $7 \mathrm{a}$ shows an enlarged section of Figure $6 \mathrm{a}$ and $\mathrm{a}$ possible fault alignment. The two vertical lines (in 7a) may mark a velocity bust. In both $6 \mathrm{c}$ and $6 \mathrm{~d}$ chaotic reflectors are thought to represent complexly disturbed areas (same as in Figure 6b). It is interesting to note that the complex disturbances labeled ' $d$ ' on Figure $6 c$ and $d$ returned no signal in Figure $6 b$.

The deconvoluted line $6 b$ shows obvious diffraction's associated with the disturbed zone on line $6 \mathrm{a}$ and on the enlarged figure 7c. Deconvolution reduces the "ringiness" common to GPR data and sharpens the contact between offset reflections. The alignment pattern shown by the arrows is thought to represent a fault plane corresponding the seismic "fz" between CPT $5 E$ and $3 E$.

Figure $6 \mathrm{c}$ is a migrated section that shows possible arcuate to linear zones of offset (enlarged on Figure 7b). Migration seems to enhance the lithological 
interpretability of the data and makes the channel cut and fill and lap features more visible. The arcuate nature of these anomalies is thought to represent anomalous velocity zones representing displaced sediments. If these zones were linear it would be possible to assume a velocity problem. These arcuate patterns are similar to the comparison models $5 \mathrm{~b}$ and $5 \mathrm{~d}$.

Figure $6 d$ is both deconvoluted and migrated. There are features on this line that may be interpretable, but generally this data appears too noisy or confused. The dip change, possibly similar to fault example $5 \mathrm{~d}$, just west of CPT-1 is consistent on this line, as it is on all GPR lines, and is probably a down to the west fault plane.

Offset reflectors, above and below reflectors that are apparently not offset, pose problems for fault continuity. The faults, for the purpose of this study, are considered continuous throughout the section because, one) many non-offset horizons show amplitude changes possibly indicating fracturing, and two) the offsets may occur out of the plane (similar to model $5 \mathrm{c}$ ) and therefore, not be visible. Additionally, faults in unconsolidated sediment often translate by grain rotation through any given bed (for example, see Bonilla and Lienkaemper, 1990).

The raw $100 \mathrm{MHz}$ data (Figure 6a) has elements of all features while the deconvoluted data (6b) enhances diffractions that may represent faults. The migrated data (6c) shows the best overall velocity and offset relationships. Figure $6 \mathrm{~d}$, the deconvoluted and migrated section is the most difficult to interpret. 
Figure $6 \mathrm{e}$ and $6 \mathrm{f}$ is the $200 \mathrm{MHz}$ data stacked and migrated, respectively. The migrated data exhibits numerous offsets and dip changes that may be interpreted as faulting, the zones of possible faulting, but not the overall configuration of the faulting, correspond well with the $100 \mathrm{MHz}$ data and with the seismic "fz's". The enlarged section on Figure 7d shows the interpreted offsets with rollover and drag. It should be noted that the linear velocity anomaly shown on $6 \mathrm{a}$ and $7 \mathrm{a}$ is also seen in the $200 \mathrm{MHz}$ data (see arrow). The channel seen on the $100 \mathrm{MHz}$ data and the CPT data is obvious on the $200 \mathrm{MHz}$ data.

Figure $6 \mathrm{~g}$ is the $300 \mathrm{MHz}$ data and images the upper 15 feet of the study area. Suggestions of the channel are present between CPT 1 and $6 \mathrm{w}$ and the dip change seen in all of the lines west of CPT-1 is also present. It is difficult to interpret whether the changes in the line between CPT-1 and 5E are associated with faulting or near surface interferences because of the shallow investigation of the data. The velocity anomaly seen on $6 a(100 \mathrm{MHz}$ data) and on $6 \mathrm{f}(200$ $\mathrm{MHz}$ ) data is present in the form of an offset zone thought to be a fault strand similar to examples $5 \mathrm{a}$ and $5 \mathrm{c}$.

\section{CONCLUSIONS}

The results of this study suggests that 1) the CPT study, combined with the monitoring well data may suggest that discontinuities in correlatable zones may indicate that faulting is present 2) the addition of the Wenner and dipole-dipole data may further suggest that offset zones exist in the shallow subsurface but not allow specific fault planes or fault stranding to be mapped 3) the high resolution seismic data will image faults to within a few feet of the surface but does not have the resolution to identify the faulting on the scale of our models, 
however it will suggest locations for upward continuation of faulted zones 4) offset $100 \mathrm{MHz}$ and $200 \mathrm{MHz}$ CMP GPR will image zones and features that may be fault planes and strands similar to our models 5) $300 \mathrm{MHz}$ GPR will image higher resolution features that may suggest the presence of deeper faults and strands, and 6) the combination of all of the tools in this study, particularly the GPR and seismic may allow for the mapping of small scale, shallow faulting in unconsolidated sediments.

\section{ACKNOWLEDGMENT}

This research was performed by the Westinghouse Savannah River Company for the U. S. Department of Energy under Contract No. DEAC09-89SR18035. Special thanks go to Traci Mickley and Shannon Vick of Westinghouse for graphics support. 


\section{REFERENCES}

Andrews, C. H., 1961, Application of the Wenner resistivity method to the detection of buried shallow faults in the Guif coastal province: M.Sc. Thesis, Texas A\&M.

Annan, A. P. and Cosway, S. W. , 1992, Ground penetrating radar survey design, Proceedings of the Symposium on the Application of Geophysics to Engineering and Environmental Problems, Vol.2, Oakbrook, Illinois,

Annan, A. P. , S. W. Cosway and J. D. Redman, 1991, Water table detection with ground penetrating radar, Expanded Abstracts, Vol. 1, p. 494-495, Society of Exploration Geophysicists 61st Annual Meeting, Houston.

Apperson, K. D. and M. Waddell, 1993, Shallow geologic structure beneath the F and H Seepage Basins, Savannah River Plant, Aiken and Barnwell Counties, South Carolina, A re-evaluation using the Landmark geophysical interpretation program, Earth Sciences and Resources Institute, University of South Carolina, Columbia, SC, ESRI Technical Report 93-11-F116. 62. p

Beck, A. E., 1981, Physical principles of exploration methods, John Wiley and Sons, New York, 234 p.

Beres, M., and F. P. Haeni, 1991, Application of Ground-Penetrating-Radar Methods in Hydrogeological Studies, Groundwater, Vol. 29, No. 3, p. 375-386. 
Bodmer, R. and S. H. Ward, 1969, Continuous sounding-profiling with a DipoleDipole Resistivity Array, Geophysics, V. 32, No. 5, p. 838-843.

Bonilla, M. G., 1972, Detailed Study of Parts of the 1971 SurfaceFaulting in the San Fernando Fault Zone, Earthquake Notes, Vol. XLII, No. 1, p. 7.

Bonilla, M. G. and J. J. Lienkaemper, 1990, Visibility of Fault Strands in Exploratory Trenches and Timing of Rupture Events, Geology, V. 18, p. 153-156.

Campbell, F. F., 1965, Fault criteria, Geophysics, V. 30 (6), p. 976-997.

Crone, A. J., and K. V. Luza. 1990, Style and Timing of HoloceneSurface Faulting on the Meers Fault, Southwestern Oklahoma, GSA Bulletin, V. 102, p. 1-17.

Cumbest, R. J., V. Price and E. E. Anderson, 1992, Gravity and Magnetic Modelling of the Dunbarton Triassic Basin, South Carolina, Southeastern Geology, V. 33, No. 1, p. 37-51.

D'Appolonia, 1979, DWPF, E. I. duPont de Nemours and Company, Wilmington, Delaware.

Davis J. L. and A. P. Annan, 1989, Ground Penetrating Radar for high resolution mapping of soil and rock stratigraphy, Geophysical Prospecting, V. 37, p. $531-551$. 
DePaor, D. G. and G. Eisenstadt, 1987, Stratigraphic and Structural Consequences of Fault Reversal, An example from the Franklinian Basin, Ellesmere Island, Geology, V. 15, p. 948-949.

Fisher, E., G. A. McMechan and A. P. Annan, 1992, Acquisition and processing of Wide-Aperture Ground Penetrating Radar Data, Geophysics, Vol. 57, No. 3, p. 495-504.

Fisher, E. McMechan, G. A., Annan, P. and Cosway, S. W., 1992, Examples of reverse-time migration of single-channel ground penetrating radar profiles, Geophysics, Vol. 57 , No. 4, p. 577-586.

Genik, G. J., 1993. Petroleum Geology of Creteceaous-Tertiary Rift Basins in Niger, Chad and Central African Republic, AAPG Bulletin, v. 77, No. 8 , $1405-1434$

Goforth, T. and C. Hayward, 1992, Seismic reflection investigations of a bedrock surface buried under alluvium, Geophysics, Vol. 57, No. 9, p. 1217-1222.

Hampton, M. A., Lee, H. J., and Beard, R. M., 1982, Geological interpretations of cone penetrometer tests in Norton Sound, Alaska, Geo-Marine Letters, Vol. 2, p. 223-230.

Haselton, T. M., and Jau-Ping Tsau, 1986, Earth Resistivity, as a Tool for Shallow Exploration in the Reelfoot Lake Area, Tennessee, Tennessee 
Department of Conservation, Division of Geology, Report of I investigations No. 43, $58 \mathrm{p}$.

Hu, L. Z., Ramaswamy, M. and B. McCormick, 1992, Delineate subsurface structures with ground penetrating radar, Houston Advanced Research Center, report, $16 \mathrm{p}$.

Killey, R. W. D. and A. P. Annan, 1990, Stratigraphic Information from Impulse Radar profiling over Unconsolidated Sands, Atomic Energy of Canada Limited Report AECL-9085/18, p. 295-306.

Krieter, C. W. and D. G. McKalips, 1978, Identification of Surface Faults by Horizontal Resistivity Profiles, Texas Coastal Zone, University of Texas at Austin, Bureau of Economic Geology, Geologic Circular 78-6, Austin, TX $23 \mathrm{p}$.

Marine, I. W. and Siple, G. E., 1974, Buried Triassic basin in the Central Savannah River Area, South Carolina and Georgia, GSA Bulletin, v. 85, p. 311-320.

Miller, R. D., D. W. Steeples, R. W. Hill and B. L. Gaddis, 1990, Identfying intraalluvial and bedrock structures shallower than 30 meters using seismic reflection techniques, in Geotechnical and Environmental geophysics, Vol 3, S. H. Ward ed., p. 89-97.

Moffat, D. L. and R. J. Puskar, 1976, A Subsurface Electromagnetic Pulse Radar, Geophysics, Vol. 41, No. 6, p. 506-518. 
Nielson, D., 1991, Practical handbook of ground-water monitoring, Lewis Publishers, Chelsea Michigan, $460 \mathrm{p}$.

Pelton, W. H., Rijo, L. and Swift, C. M., 1978, Inversion of two-dimensional resistivity and induced -polarization data, Geophysics, vol. 43, no. 4, p. 788-803).

Roberts, R., J. L. Daniels and M. Vendl, 1991, Seasonal variations and ground penetrating radar data repeatability, Expanded Abstracts, Vol. 1, p. 486489.,Society of Exploration Geophysicists 61st Annual Meeting, Houston.

Robertson, P. K. and Campanella R. G., 1989, Guidelines for geotechnical design using the cone penetrometer test and CPT with pore pressure measurement, Fourth Edition, Civil Engineering Department, University of Alberta, $226 \mathrm{p}$.

Roth, W. H., R. F. Scott and I. Austin, 1981, Centrifuge Modeling of Fault Propogation through Alluvial Soils, GRL, V. 8, No. 6, p 561-564.

Ross, H. P., C. E. Mackelprang and P. M. Wright, 1990, Dipole dipole electrical resistivity surveys at waste disposal study sites in northern Utah, in Geotechnical and Environmental Geophysics, Vol 2, S. H. Ward ed. p. 145-152.

Seeber, L. and J. G. Armbruster, 1983, Large Strain Effects of the 1886 South Carolina Earthquake, in proceedings of Conference $X X$, "A Workshop on 
the 1886 Charleston, South Carolina Earthquake and its Implications for Today" W. W. Hays and P. L. Gori, eds. USGS OP-83-843.

Sexton, J. L. and P. B. Jones, 1986, Evidence for recurrent faulting in the New Madrid Seismic Zone from Mini-Sosie high resolution reflection data, Geophysics, Vol. 51, No. 3, p. 1760-1788.

Sheriff, R. E., 1982, Structural interpretation of seismic data, Education Course Note Series \#23, AAPG, Tulsa, 73 p.

Smith, D. G. and H. M. Jol, 1992, Ground penetrating radar investigation of a Lake Bonneville delta, Provo Level, Brigham City, Utah, Geology, v. 20, p. $1083-1086$.

Stearns, R. G., S. L. Wison and S. J. Nava, 1986, Post-Eocene Fault Near East Edge of Reelfoot Rift in Lauderdale County, Tennessee, as Discovered by Gravity, Earth Resistivity Surveys, and Drilling, NUREG/CR-4702, US Nuclear Regulatory Commission, Washington, DC.

Stephenson, D. E., 1985, Savannah River Plant Earthquake of June 1985, DPST-85-583, E. I. du Pont de Nemours \& Co., Aiken, SC

Stephenson, D. E., 1988, August 1988 Savannah River Plant Earthquake, DPST-88-841, E. I. du Pont de Nemours \& Co., Aiken, SC. 
Stephenson, W. J., J. Odum, K. M. Shedlock, T. L. Pratt and R. A. Williams,

1992, Mini-Sosie High-resolution seismic method aids hazard studies, Eos, v. 73, n. 44, p. $473-475$.

Ulriksen, C. P. F., 1982, Application of impulse radar to civil engineering, Lund University of Technology, $179 \mathrm{p}$.

Ward, S. H., 1990, Resistivity and induced polarization methods, in Geotechnical and Environmental Geophysics, Vol. 1, S. H. Ward ed., p. 147-189.

Witboard, R. R. Grannell, H. Shifflet, E. Ambos, T. Potter and G. Simila, 1993, Geophysical, geodetic and geologic study of the San Andreas Fault system near Mecca, CA, poster session, 1993 Annual Meeting of the Symposium for the Application of Geophysics to Engineering and Environmental Problems, San Diego.

Wyatt, D. E., R. V. Brodine, G. B. Sexton and R. J. Pirkle, 1993, Advancements in Environmental Applictions of Ground Penetrating Radar, WSRC-MS93-499, Proceedings of the Environmental Restoration '93 Conference, October 25-28, 1993, Augusta, Georgia. 


\section{Figure Captions}

Figure 1: The Savannah River Site lies within the South Carolina/Georgia coastal plain of the southeastern US.

Figure 2: A portion of the geologic cross-section showing possible faulting based on borehole geological and geophysical correlations. The lithology underlying the study area is also shown. The original faulting was inferred from discontinuous or non-correlatable bedding between adjacent wells.

Figure 3: Comparison of resistivity and dipole-dipole data generated from this study. The seismic shotpoints are listed across the top of the figure and the CPT locations with distances are also shown. Fig. 3A is the summary crosssection created from the CPT. The lithology for the monitoring wells is given in detail on Figure 2. The gamma ray curves from the adjacent monitoring wells are shown for comparison with the Friction Ratio curves of the CPT. The resistivity curve from monitoring well HSB-69 is also shown for comparison. The shaded areas are interpreted sand units that are highlighted for comparison. Figure 3B presents the combined resistivity data from the Wenner sounding/profiling and the dipole-dipole survey. Apparent resistivity values are plotted in ohm-feet. Contours were generated with a simple least-squares computerized mapping program. "A" and " $\mathrm{N}$ " spacings are shown on the left and depths calculated according to Beck (198?) on the right.

Figure 4: Part of the high resolution east-west seismic data that suggested the presence of basement involved faulting. Zero to $409 \mathrm{~ms}$ of data are shown. The "R" represents the maximum depth of exploration for the $100 \mathrm{MHz}$ GPR 
data, the "D" the calculated maximum depth of exploration for the dipole-dipole data. The " $\mathrm{K}$ " is the top of the Cretaceous, and the " $\mathrm{B}$ " is basement. The well symbols are for the monitoring well locations and each vertical tic mark corresponds to a CPT location. Interval velocity analysis indicates that $0.1 \mathrm{~ms}$ is $25^{\prime}, 0.2 \mathrm{~ms}$ is $50^{\prime}$ and $0.3 \mathrm{~ms}$ is $75^{\prime}$. The top of Cretaceous is $100 \mathrm{~ms}$ or 265 feet. Basement is at $350 \mathrm{~ms}$ or approximately 1000 '. The coastal plain sediments dip from west $(W)$ to east $(E)$ and this seismic line probably cuts the faulting obliquely. The morphology of the fault systems suggests that this fault is an extension/growth fault with some possible strike-slip components.

Figure 5: Shallow faulting examples used for comparisons with this study. Note the scale of the features. Figure $A$ is from Bonilla and Lienkaemper $(\div 990)$ and demonstrates fault stranding. Figure B is from Witboard et al (1993) for shallow slumping and faulting along the San Andreas. Figure $C$ is a schematic of actual normal and reverse faulting, and clastic dike emplacement observed from trenching a few miles from the study area (D'Appolonia, 1979). Figure $D$ is from Roth et al (1981) and is a theoretical example of faulting observed from centrifuge modeling in cohesive soils.

Figure 6a-g: GPR data comparisons. The locations of the CPT correlation holes are shown as well as the projections of the faulting from Figure 3. Depths in nanoseconds are shown on the right. "WT" is the water table measured from well HSB-69. Individual line interpretations are discussed in the text and processing data in Table 1. 
Figure 7a-e: $\quad$ Enlarged sections of Figure 6. 7a is "raw" $100 \mathrm{MHz}$ data. 7b

is migrated and $7 \mathrm{c}$ is deconvoluted data. $7 \mathrm{~d}$ is $200 \mathrm{MHz}$ data and $7 \mathrm{e}$ is 300 $\mathrm{MHz}$ data all discussed in the text.

Table 1: Processing applied to the GPR data. The shaded area is for the $200 \mathrm{MHz}$ data. 


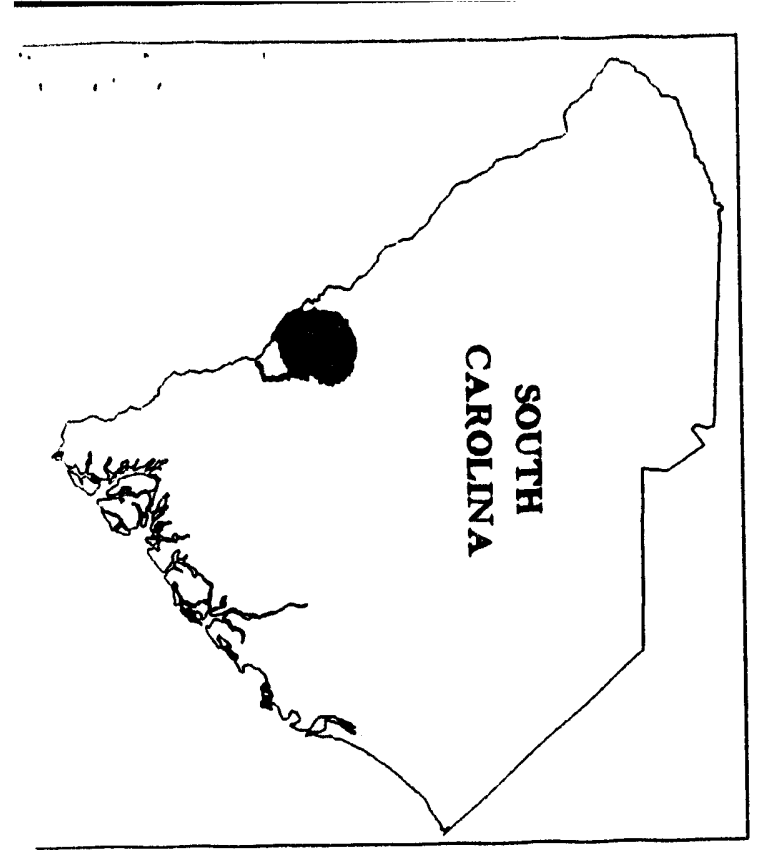

Figure 1 

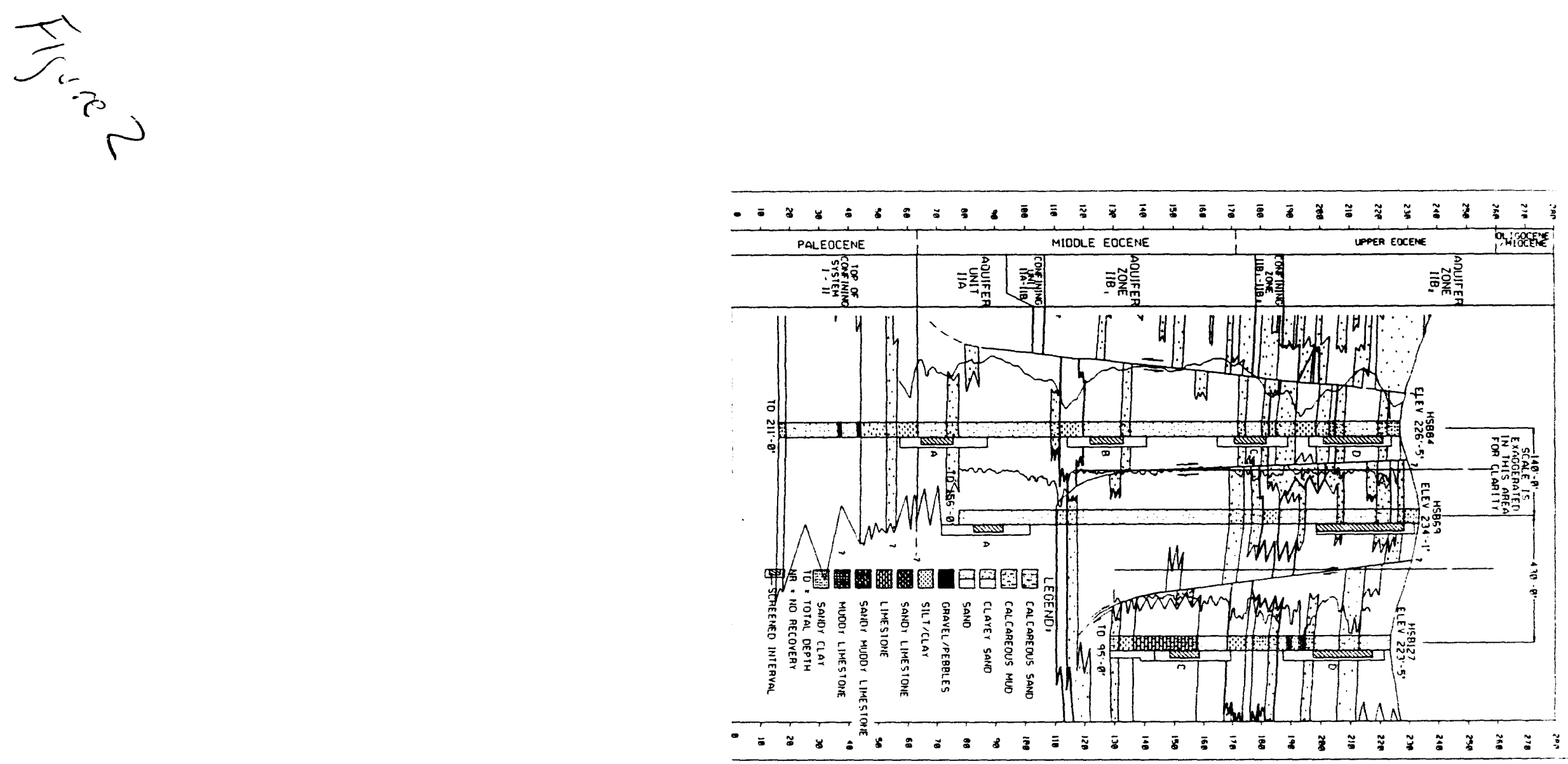


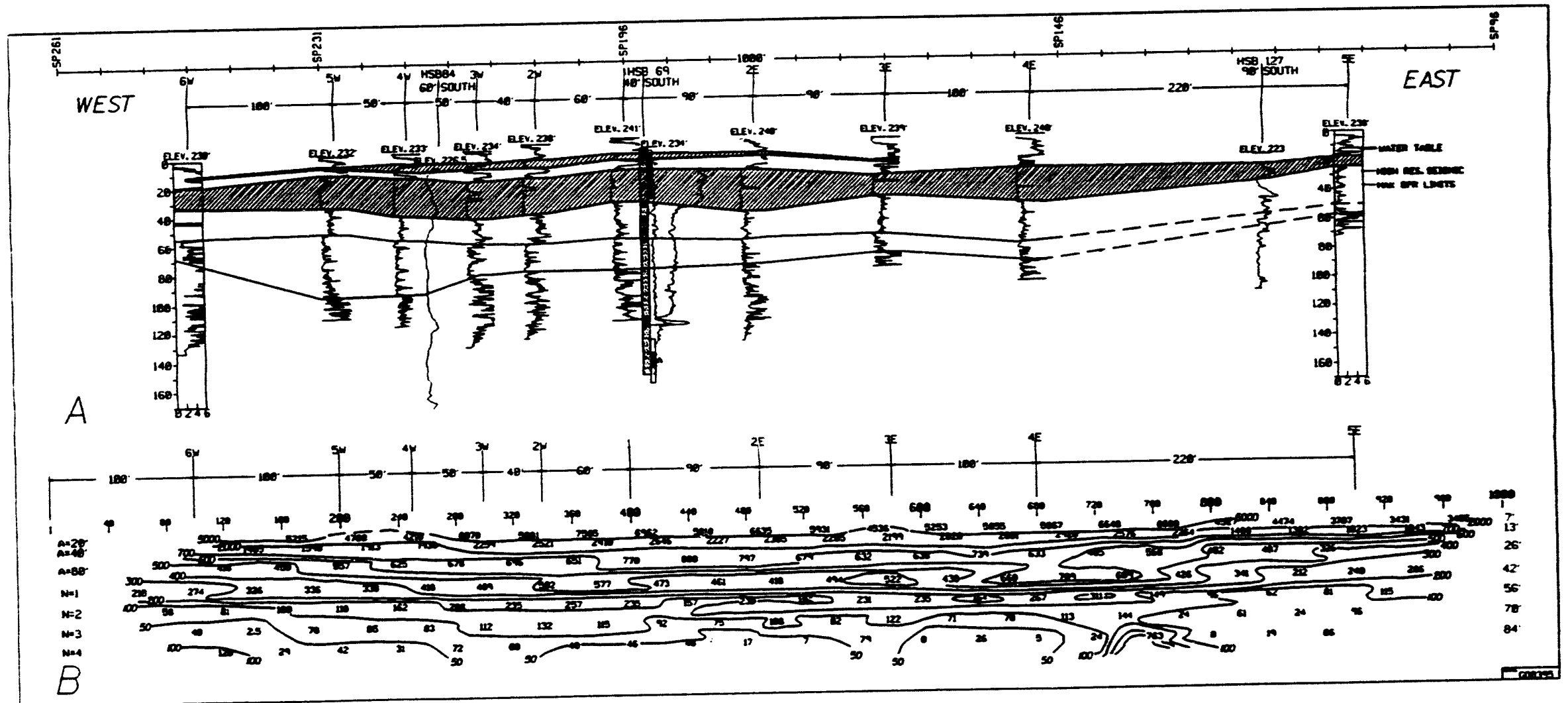




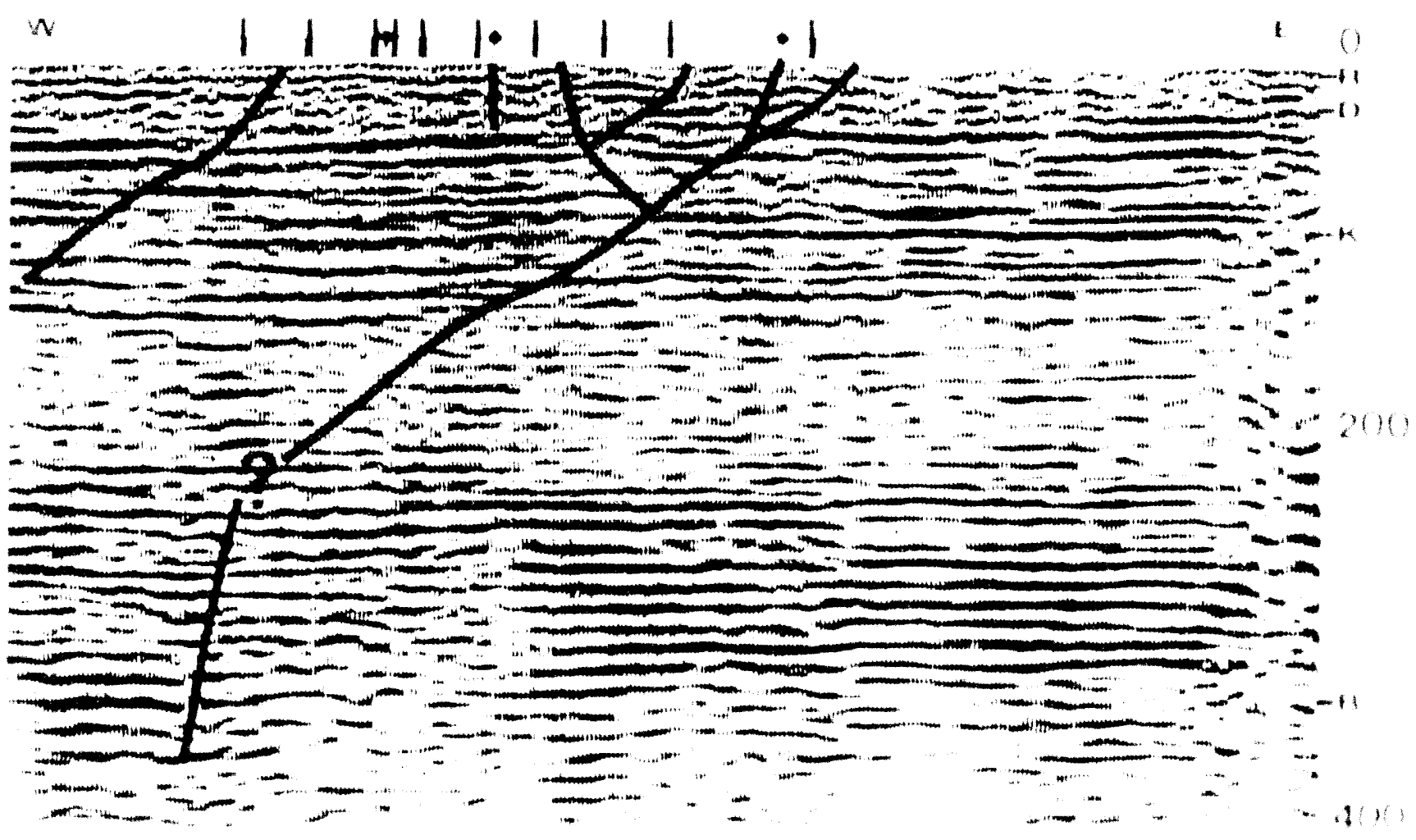




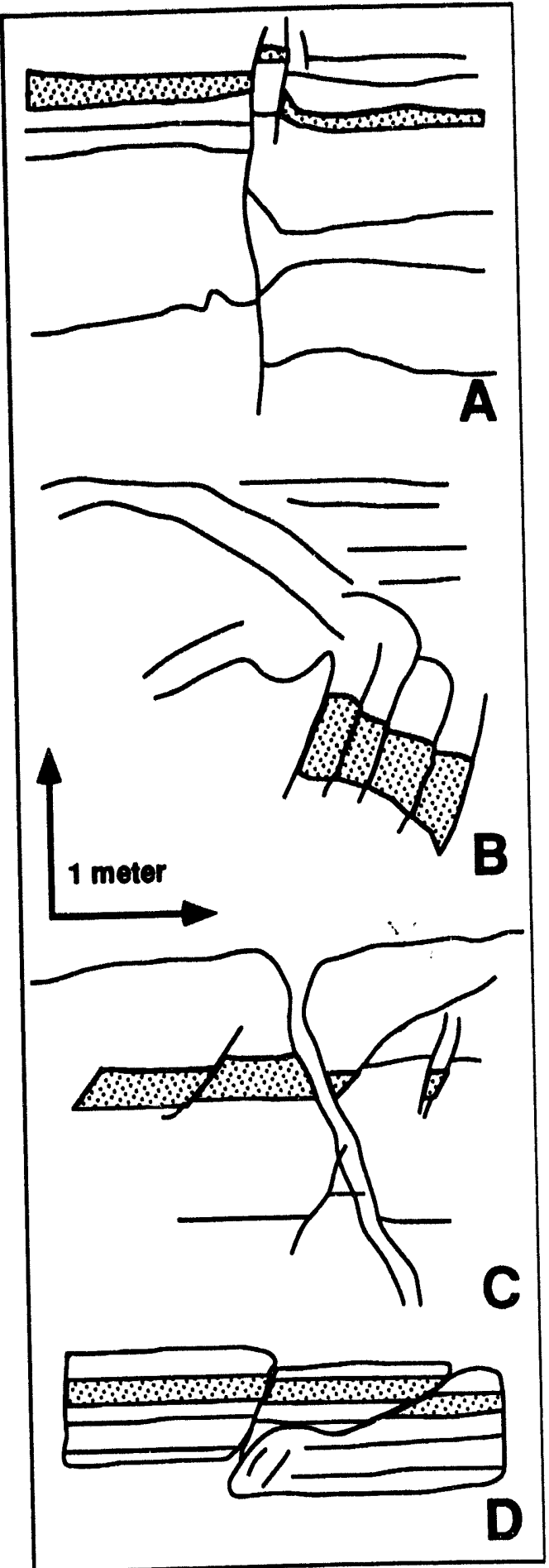

rises 

$+100 \mathrm{ft}+$

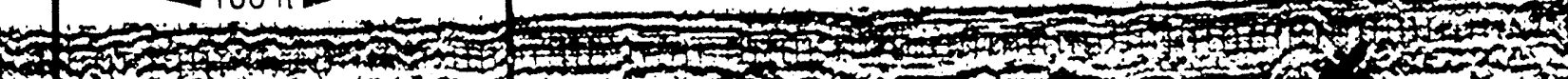

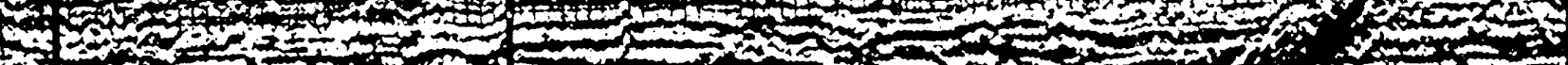

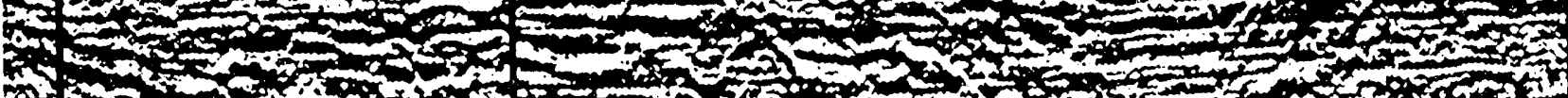

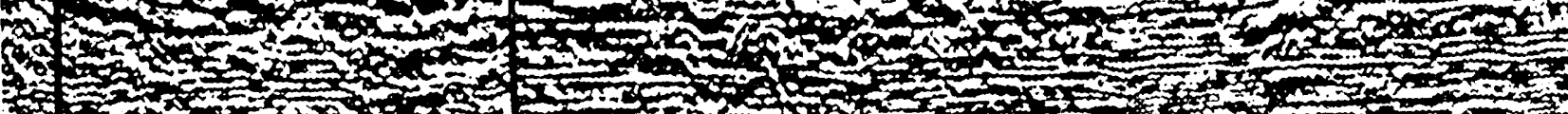

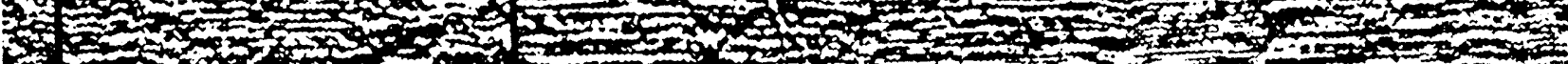

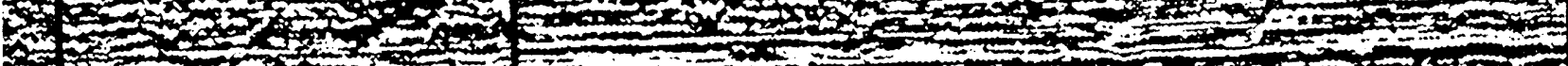
2

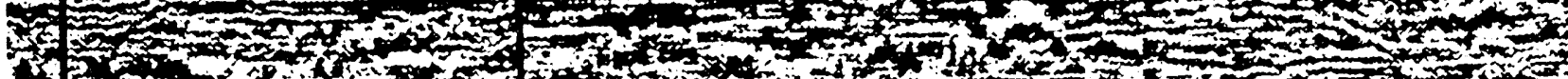

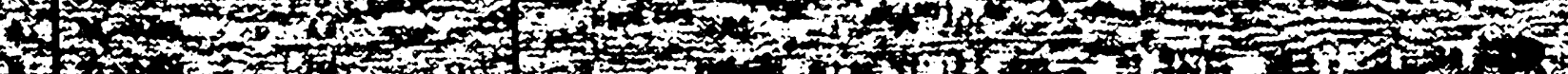

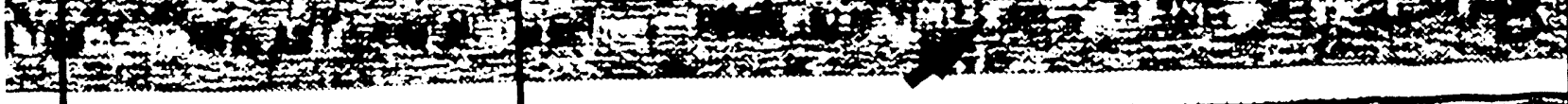

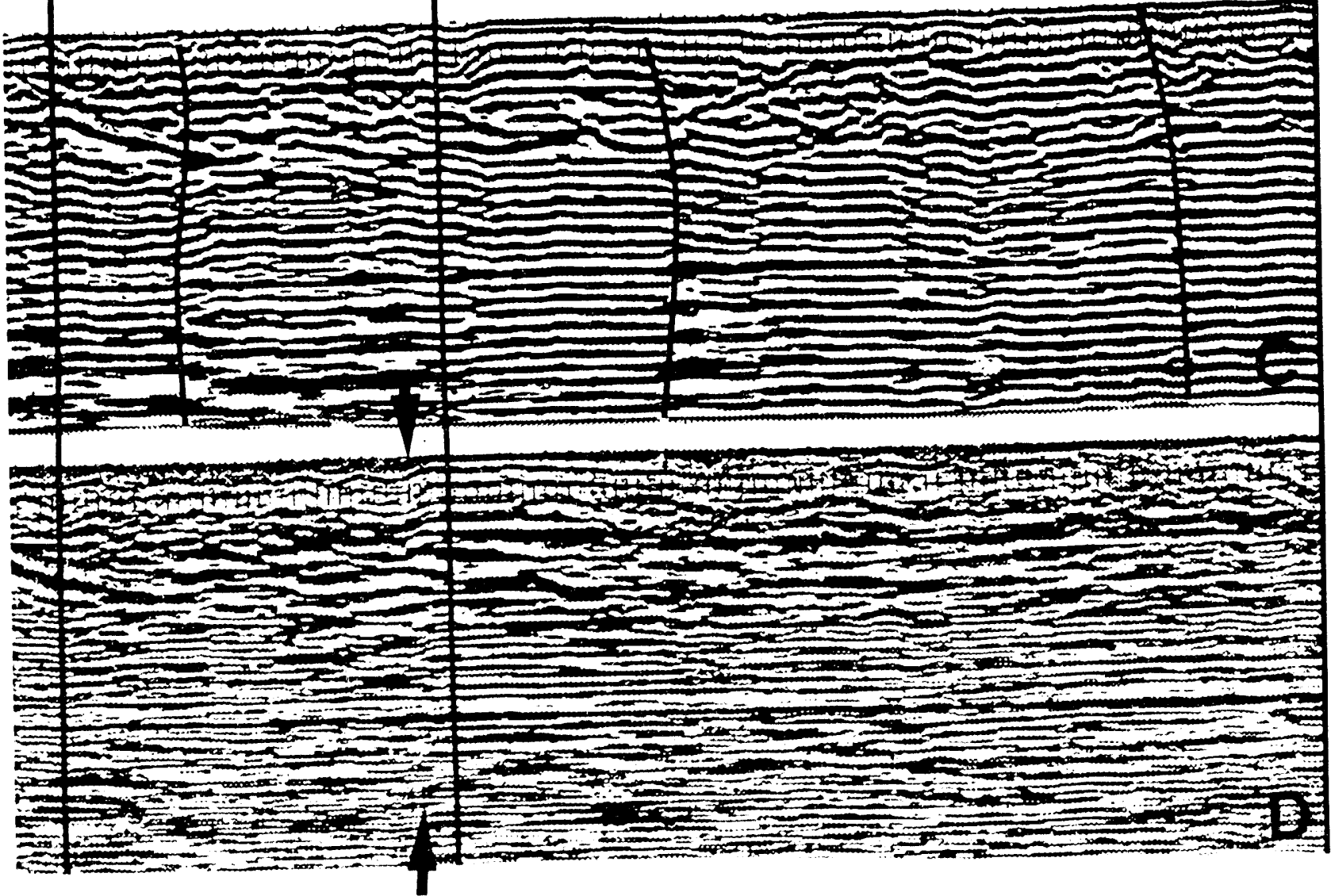




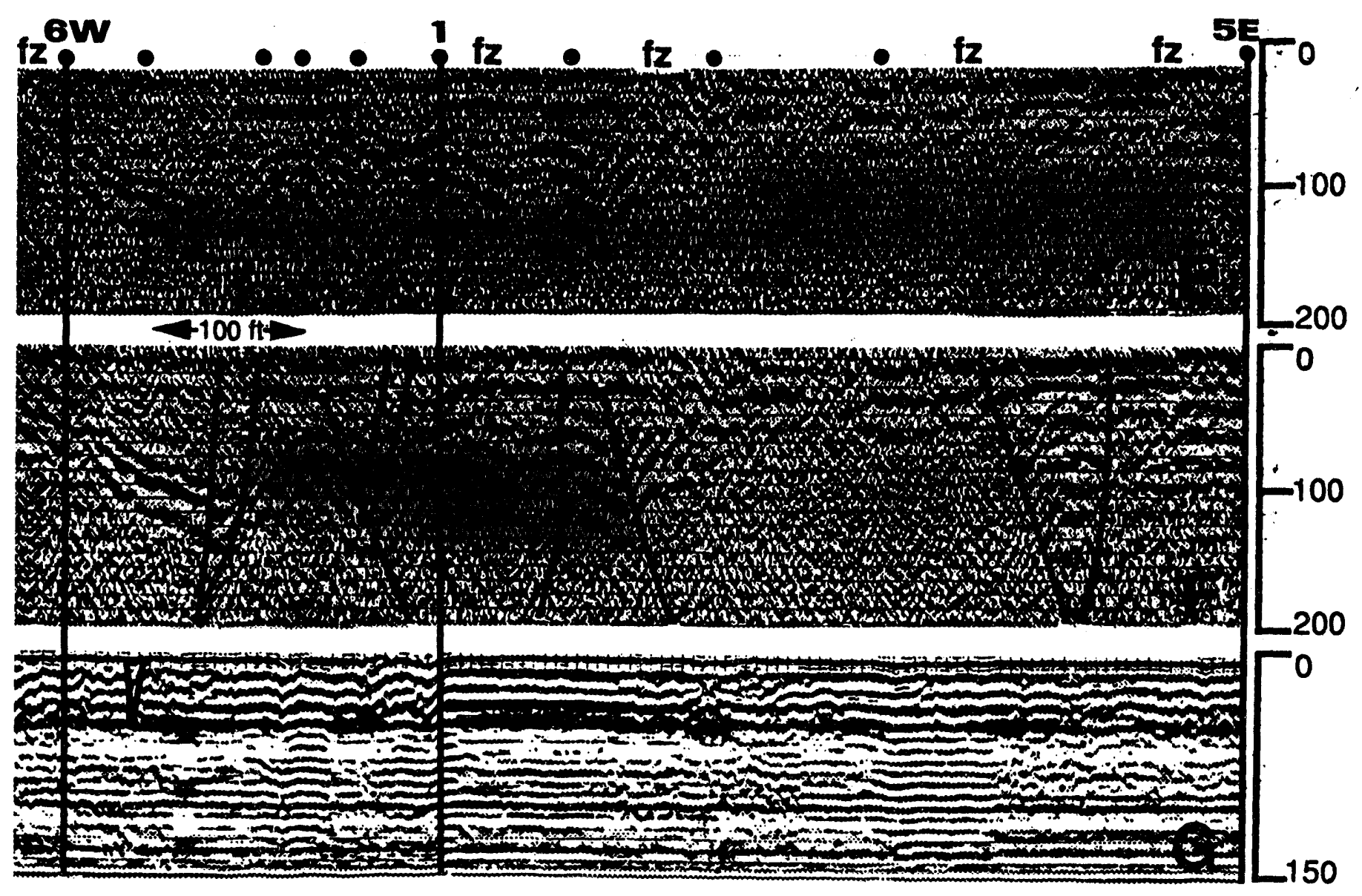

Fipure 6 

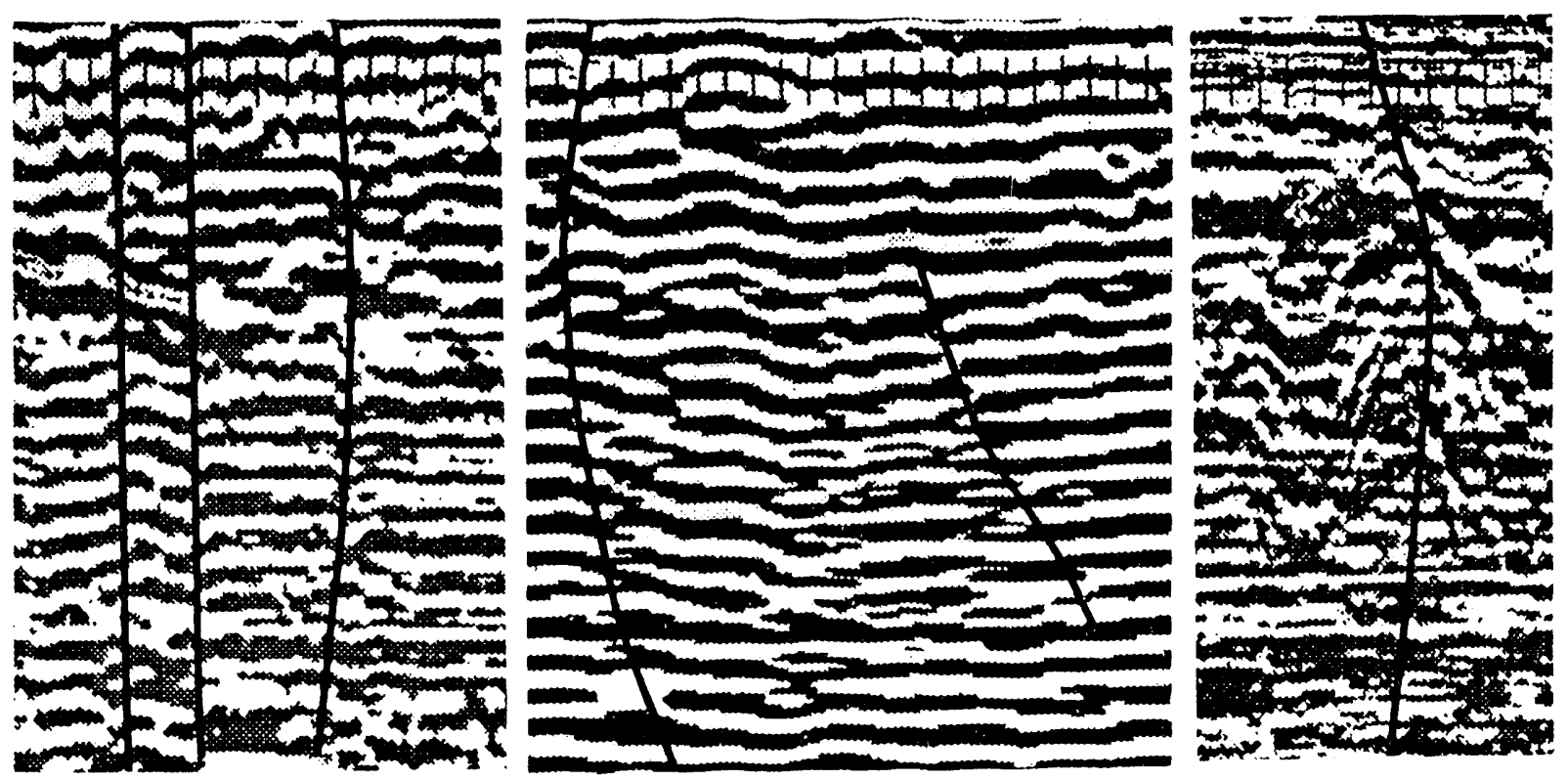

A

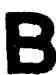

C

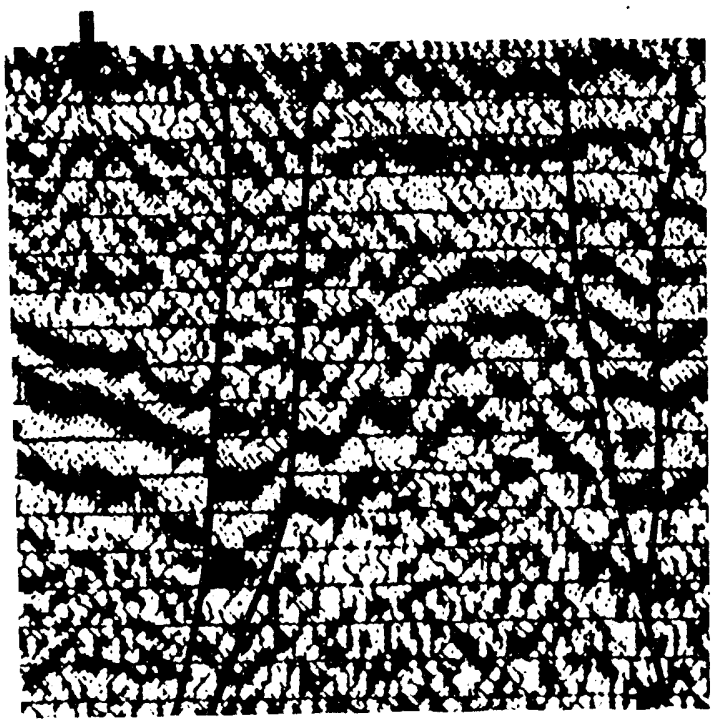

D

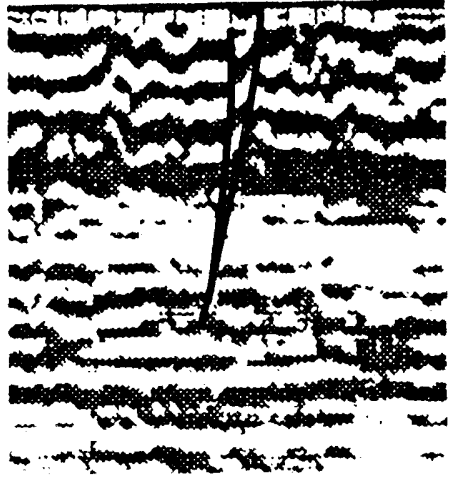

$=$ 


\begin{tabular}{|c|c|c|c|c|c|c|c|}
\hline \multirow{2}{*}{$\begin{array}{l}\text { Processing } \\
\text { Steps }\end{array}$} & \multicolumn{7}{|c|}{ Figure 5 GPR Lines } \\
\hline & $5 \mathrm{~A}$ & $5 B$ & $5 C$ & 5D & $5 E$ & $5 F$ & $5 \mathbf{G}$ \\
\hline $\begin{array}{l}\text { Frequency } \\
(M H Z)\end{array}$ & 100 & 100 & 100 & 100 & $\begin{array}{l}200 \\
\text { CDP }\end{array}$ & $\begin{array}{l}200 \\
\mathrm{CDP}\end{array}$ & 300 \\
\hline $\begin{array}{l}\text { Samples(Rate) } \\
\text { ScanLength(ns) }\end{array}$ & $\frac{512}{600}$ & $\frac{512}{600}$ & $\frac{512}{600}$ & $\frac{512}{600}$ & $\begin{array}{l}0.8 n s \\
1000 \mu 1.5\end{array}$ & $\begin{array}{l}0.8 n s \\
1009 u s\end{array}$ & $\frac{1024}{300}$ \\
\hline $\begin{array}{c}\text { Vertical } \\
\text { High Cut }\end{array}$ & $\mathbf{x}$ & $x$ & $\mathbf{x}$ & $\mathbf{x}$ & & & $x$ \\
\hline $\begin{array}{l}\text { Vertical } \\
\text { Low Cut }\end{array}$ & $\mathbf{x}$ & $\mathbf{x}$ & $\mathbf{x}$ & $\mathbf{x}$ & & & $\mathbf{x}$ \\
\hline $\begin{array}{l}\text { Horizontal } \\
\text { Low Cut }\end{array}$ & $x$ & $x$ & $x$ & $x$ & & & $x$ \\
\hline Deconvolution & & $\mathbf{x}$ & & $\mathbf{x}$ & & & \\
\hline $\begin{array}{l}\text { Migration } \\
\text { (Kirchoff) }\end{array}$ & & & $\mathbf{x}$ & $\mathbf{x}$ & & & \\
\hline $\begin{array}{l}\text { Presiadk } \\
\text { fillering }\end{array}$ & & & & & $\mathbf{X}$ & $\mathbf{x}$ & \\
\hline Stacking & & & & & $\mathbf{X}$ & $\mathrm{x}$ & \\
\hline $\begin{array}{l}\text { Migration } \\
\text { (WEM) }\end{array}$ & & & & & & $x$ & \\
\hline
\end{tabular}

Table 1 

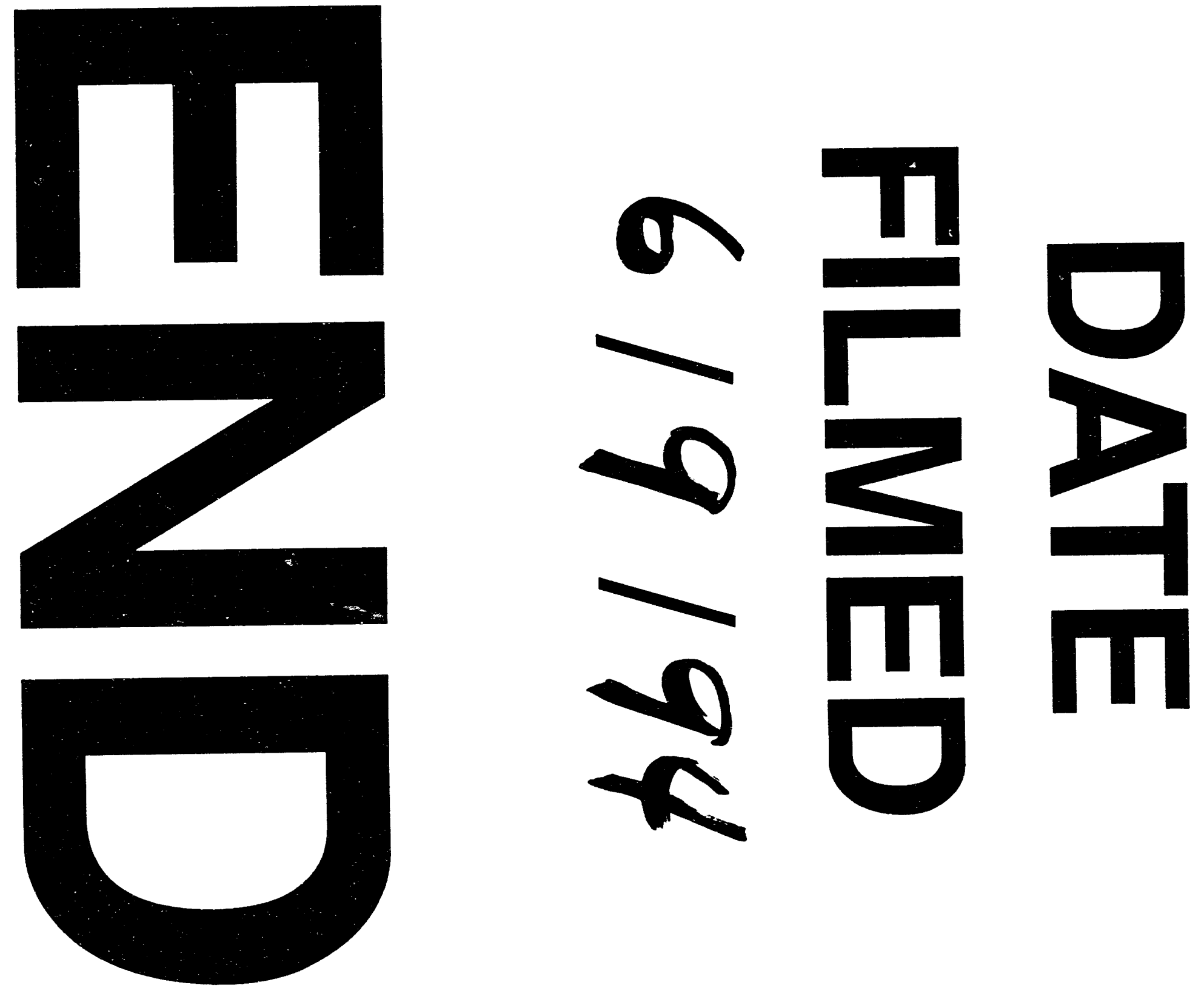
